\title{
Az urbanizációs folyamatok megjelenése Budapest környékén \\ Előtanulmány egy történeti szempontú urbanizációs modell kidolgozásához
}

\section{Beginnings of urbanisation processes as exemplified by the Budapest Metropolitan Area Preface to a historical model of urbanisation}

\author{
BUSKó TIBOR LÁSZLó, JóSZAI ATTILA
}

BUSKó Tibor László: adjunktus, Nemzeti Közszolgálati Egyetem, Közigazgatás-tudományi Kar; Busko.Tibor@uni-nke.hu JósZAI Attila: tanársegéd, Nemzeti Közszolgálati Egyetem, Közigazgatás-tudományi Kar; Joszai.Attila@uni-nke.hu

KULCSSZAVAK: urbanizációs szakaszok, budapesti agglomeráció, evolúciós iskola, történeti iskola

ABSZTRAKT: A magyarországi, ezen belül a főváros térségében tapasztalható urbanizációs folyamatok vizsgálata viszonylag széles körben foglalkoztatta a hazai kutatókat az utóbbi évtizedekben. A kutatások jórészt az urbanizációs folyamatok szakaszolhatóságára vonatkozó, van den Berg és Drewett által kifejtett, majd Enyedi György által továbbgondolt modell alapján szolgáltattak újabb és újabb adalékokat a föváros térségében zajló urbanizációs folyamatok megértéséhez. Tanulmányunkban a korabeli statisztikai kiadványok feldolgozásával egy olyan adatbázist építettünk ki, amely lehetővé teszi, hogy az eddigieknél is pontosabb képet kapjunk a főváros térségének 1945 előtti urbanizációs folyamatairól. Vizsgáltuk egyrészről az urbanizációs folyamatok intenzitását (ennek során elkülönítettük egymástól a közvetlen urbanizációs zónához és a tágabb urbanizációs zónához tartozó, valamint az urbanizációs folyamatból kimaradó települések csoportját), másrészről az urbanizációs folyamatok jellegét (az ipari övezethez, a munkás-, tisztviselő- és nyaralótelepek övezethez, a város mezőgazdasági ellátóövezetéhez tartozó települések elkülönítésével). Az egyes zónák és övezetek tér- és időbeli megjelenése, elterjedésük dinamikájának sajátosságai alkalmasak lehetnek arra, hogy egy történeti szemléletű megközelítéssel pontosítsuk az úgynevezett evolúciós iskola urbanizációs folyamatok szakaszolhatóságára vonatkozó megállapításait.

Tibor László BUSKó: senior lecturer, Faculty of Public Administration, National University of Public Service, Budapest; Busko.Tibor@uni-nke.hu

Attila JósZAI: assistant lecturer, Faculty of Public Administration, National University of Public Service, Budapest; Joszai.Attila@uni-nke.hu

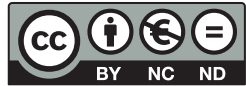


KEYWORDS: urbanisation phases, Budapest Metropolitan Area, evolutionary school, historical school

ABSTRACT: Investigating Hungarian urbanisation processes - especially when using the example of the Budapest Metropolitan Area - has been a central research topic of the Hungarian regional science discourse during the last decades. Research work increasingly contributed to better understand those urbanisation processes, on the basis of a model of urbanisation elaborated by Leo van den Berg and - as for the Hungarian literature - György Enyedi.

This article begins with a theoretical introduction that conceptualises the two most important approaches to urbanisation, the "evolutionary school" and the "historical school". The evolutionary school can be interpreted as a group of theories that identifies urbanisation as a universal process of successive "stages of urban development". Representatives of the evolutionary school set out from van den Berg's terminology which identifies four stages of urbanisation: urbanisation, suburbanisation, desurbanisation and reurbanisation.

In contrast, the achievements of the historical school are relatively unknown. This is because it concentrates not on popular - and, sometimes, slightly simplistic - generalisations, but rather on characteristics of individual trajectories of urbanisation. Of course, representatives of the historical school do not deny the existence of phases of urbanisation. They merely postulate that the intensity, extension and even the chronological order of urbanisation phases can vary from city to city.

Joining forces with the historical school, the second part of the article tries to formulate a clearer notion of urbanisation phases within the context of the Budapest Metropolitan Area during the period of 1900-1945. Using contemporary statistical publications, we built a database that helps to quantify the intensity of urbanisation processes. We were able to distinguish settlements falling under the "closest urbanisation zone", settlements falling under the "broader urbanisation zone" and settlements that did not participate in any urbanisation processes at all.

At the same time, we aimed to understand the character of urbanisation processes, by distinguishing settlements falling under "industrial area", "labourer, employee and holidaymaker colonies" and settlements falling under the "agricultural supply area of the city".

In any case, this study should be interpreted as preliminary. The authors aim to collect "raw material" for their future research, based chiefly on archival sources. However, this preliminary study - especially the spatial and chronological identification of zones and areas and the characteristics of their spreading - may be suitable for specifying a model of the so-called "evolutionary school" on urbanisation phases by means of a historical approach.

\section{Kulcsfogalmak}

A magyarországi, ezen belül a főváros térségében tapasztalható urbanizációs folyamatok vizsgálata viszonylag széles körben foglalkoztatta a hazai kutatókat az utóbbi évtizedekben. A jelenség vizsgálata a nemzetközi urbanisztikai trendeknek megfelelően a hetvenes években indult Magyarországon, majd mérföldkövét a 2012-ben elhunyt Enyedi György akadémiai székfoglalója jelentette 1982-ben. A kutatások jórészt az urbanizációs folyamatok szakaszolhatóságára vonatkozó, van den Berg és Drewett által kifejtett (van den Berg, Drewett, Klaassen, Rossi, Vijverberg 1982), majd Enyedi György által továbbgondolt (Enyedi 1988) és később többek által finomított modell törvényszerűségei alapján szolgáltattak újabb és újabb adalékokat a főváros térségében zajló urbanizációs folyamatok vizsgálatához. A témával foglalkozó szakirodalom elsősorban azon 
korszakok vizsgálatára fókuszált, amelyekből elegendő mennyiségü, esetlegesen empirikus kutatással is kiegészíthető statisztikai adat állt rendelkezésre. Így jóval nagyobb hangsúly helyeződött napjaink, valamint a húsz-harminc évvel ezelőtti folyamatok vizsgálatára, az 1945 előtti időszak méltánytalanul kevés figyelmet kapott.

Célunk ezért az, hogy a főváros térségének 1945 előtti urbanizációs folyamatait egy történeti szempontú urbanizációs modellel minél részletesebben feldolgozva felülvizsgáljuk az evolúciós iskola e korszakra vonatkozó dogmatikus megállapításait, és ha szükséges, cáfoljuk annak megállapításait.

Vizsgálatunk első lépcsője előtanulmány-jellegű. Tanulmányunk mindössze azt tüzi ki célul, hogy a korabeli településsoros statisztikai adatbázisok feldolgozásával egy olyan nyersanyaghoz jussunk, amely segítséget nyújthat későbbi - elsősorban levéltári - kutatásainkhoz. Hipotézisünk szerint a rendelkezésre álló statisztikai adatok kiértékelése mellett - melyekre alapvetően az evolúciós iskola szakaszolása épül - legalább ilyen fontos információkat nyújthat a helytörténet. Ehhez a levéltári kutatások, községi iratok tanulmányozása mellett a már feldolgozott helytörténeti munkák is komoly támpontot biztosíthatnak. Mert azt, hogy mit is jelentett pontosan egy település számára az, hogy részévé vált valamely urbanizációs zónának és övezetnek, csak a részletesebb kutatásaink során tudjuk feltárni.

A korszakra vonatkozóan ezért új eredményeket, a „közmegegyezésen” alapuló tendenciák, folyamatok (vö. urbanizációs szakaszok) megerősítését, esetleg megcáfolását csak lokális, mikrotérségi történeti kutatások hozhatnak. Az empirikus jellegü történeti kutatások szükségességére Timár Judit hívja fel a figyelmet (Timár 2006), hivatkozva Beluszky, Berényi, valamint Dövényi és Kovács kutatásaira, akik az urbanizációs folyamatok 1945 előtti, korai megjelenésére utaló jellegzetességeket hangsúlyozzák tanulmányaikban.

A komplex kutatással célunk tehát az, hogy az evolúciós iskola megállapításait történeti szemléletű megközelítéssel igazolhatóvá vagy cáfolhatóvá tegyük; a helyi, mikrotérségi jellegzetességek elemzésével pontosítani tudjuk a korábban megfogalmazott megállapításokat. ${ }^{1}$

Ezért arra kényszerülünk, hogy az általános érvényűségre törekvő szakaszelméletet szükség esetén revideáljuk. Hiszen kutatásunk ugyan történeti jellegü, de második fázisában az empirikus jelleg érvényre juttatására törekszik. Mindezek miatt lássuk a történeti és az evolúciós iskola felfogása közti különbségeket!

A történeti iskola nézetei kevésbé ismertek, elsősorban talán azért, mert nem modellekben, sematizálható törvényszerűségekben gondolkodik, hanem az egyediséget hangsúlyozza. A történeti iskola létrejöttét az evolúciós iskolának köszönheti, arra reagál - véleményünk szerint értelmezési keretrendszerében valójában csak cizellálja annak megállapításait. Képviselői nem tagadják az evolúciós iskola szakaszolását, pusztán annyit állítanak, hogy az egyes szakaszok intenzitása, területi kiterjedtsége, sőt egyes esetekben akár sorrendje városonként változhat, ezért nézeteik homlokterében nem az evolúciós modellben 
elhelyezett város áll, hanem maguk a városfejlődési folyamatok. Ezek megfogalmazása sem egyszerü, és még napjainkban sincs teljes egyetértés a nézet képviselői között, hogy lehetséges-e egyáltalán a városfejlődési folyamatokat tipizálni (Saunders 1985; Savage, Warde 1993). Ha igen, úgy az hasonlóan sematikus jelleggel bír, mint az evolúciós iskola szakaszolása, csak éppen más struktúrában. Ezzel igazolhatjuk is, hogy az urbanizációs folyamatok modellezésével (melyek lehetnek térbeliek vagy funkcionálisak) nincs probléma, a kérdés inkább az, hogy - harmadik frontot nyitva - egy várostérség urbanizálódását miként lehet vagy lehet-e egyáltalán egységesen kezelni. Lehetséges-e, akár egy nagyváros esetében is, hogy a városrészenként különböző - földrajzi, gazdasági, környezeti - okok miatt az eltérő jellegű, intenzitású városfejlődési folyamatok konvergálnak, majd egyszer csak belesimulnak valamelyik jól azonosítható evolúciós szakaszba? Azaz vizsgált területünk szempontjából a történeti iskola egyediséget hangsúlyozó szemléletére támaszkodva a választ az evolúciós iskola szakaszolásával kell keresnünk.

A chicagóiak városökológiai elmélete a húszas évek végéig elegendőnek bizonyult az amerikai városok fejlődési folyamatainak vizsgálatához. A következő évtizedekben azonban új, addig ismeretlen folyamatok jelentek meg: a városok tere kitágult, miközben népességük stagnált vagy növekedési ütemük jelentősen lassult; a nagyvárosok környékén speciális terek, kertvárosok alakultak ki. A kertvárosok minőségileg új elemet jelentettek, a folyamatot az urbanizáció - mint városodás - fogalmának kibővítésével, a szub előtag - „alatt”, valami (a város) alá - hozzátoldásával jellemezték. Így a szuburbanizáció fogalma eredeti formájában a városon kívüli, attól távolabbra lévő olyan lakóövezeti gyűrű megjelenése, amelynek lakói változatlanul a központi város szolgáltatásait veszik igénybe, ott van a munkahelyük, csupán az élhetőbb környezet iránti igényük miatt nem egyezik meg ezzel választott lakóhelyük. A fogalom azonban a későbbiek folyamán - az eredeti tartalomhoz képest - jelentősen kibővült.

Az urbanizációs szakaszok megkülönböztetésének eredeti forrása a bécsi jelentés (van den Berg, Drewett, Klaassen, Rossi, Vijverberg 1982), amely négy szakaszt különböztet meg. Az első szakasz a koncentráció (klasszikus urbanizáció vagy „városrobbanás”), melynek szinte kizárólagos előidézője az ipar: ${ }^{2}$ a csekély mobilitású lakosság igyekszik a gyárterületek környezetében letelepedni. Ezt követi a szuburbanizáció, amelyet a jelentés két további szakaszra bont. Az első a relatív koncentráció, amikor a város népességszámának növekedése lelassul a környező településgyűrű rovására, majd a második szakasz a relatív decentralizáció, amikor a központi város népessége először stagnál, majd csökken, ezzel egyidejüleg pedig - bár csökkenő ütemben, de - a városgyürü növekedése még tart. A fejlődés harmadik szakaszában a teljes várostérség népességcsökkenése a jellemző, ez a - több kutató által később két további részre bontott - dezurbanizáció. Ebben a szakaszban a tágabb - másodlagos - várostérség kisvárosi hálózata fejlődik. Innen pedig kettéválhat a feltételezett fejlődés: egyik iránya a reurbanizáció, azaz a belső város lakóövezeteinek lakófunkcióval való ismételt megtöltő- 
dése, a másik pedig az a továbbra is centrifugális tendencia, amely új növekedési pólust hoz létre, eredeti városunk pedig csak egyetlen szereplő lesz a többi között. A bécsi jelentés óta eltelt időszakban több, időnként ezzel a tagolással szinte egyező, apróbb kiegészítésekkel, módosításokkal tarkított (Enyedi 1988; Tózsa 2011), és időnként kissé - főleg a szakaszok jellemzőit illetően - eltérő (Gaebe 2004) modellek is születtek. Mindegyikük a területi koncentrálódást veszi alapul, melynek alapvető oka, hogy a magasabb szintü tevékenységek (a hagyományos kereteket szétfeszítő gyáripari termelés) munkahelyi koncentrációjával a népesség is koncentrálódik. A munkahelyi koncentrációval egyidejűleg, de általában eltérő ütemben és mértékben zajlik a lakóhelyek koncentrációja (Tóth 2006). Az urbanizációs folyamatok kutatásának elhanyagolt, de legalább ennyire fontos része kellene, hogy legyen a társadalmi, szociológiai változások vizsgálata. Így ki kell emelnünk az életmód, a foglalkozás és a lakókörnyezettel szemben megváltozott igényszint - történetileg csak körülményesen kutatható - változását, valamint a népességszám alakulásánál lényegesen sokszínűbb eredményekkel kecsegtető lakóhelyi migrációs kutatások lehetőségét. Ezek szükségére csupán néhány hazai kutató (Dövényi, Kovács 1999; Tóth 2006) hívja fel a figyelmet, akár konkrétan, akár munkája részeredményeivel. Cizelláltabb a szuburbanizációs jellemzők megítélése. Ennek egyik lehetséges oka, hogy a folyamat időben jelentősen elnyúlik, ezért más-más szempontok merülnek fel a különböző idöszakok empirikus kutatásaiban. Másrészt a szuburbanizációs jellemzők történeti távlatokban gyakran nehezen ismerhetők fel: ahogy napjainkban is megjelenhetnek a főváros környékén dezurbanizációs, sőt reurbanizációs jellemzők, úgy a klasszikus urbanizációs szakaszban is - axiómánk szerint az általánosan elfogadottnál jóval nagyobb mértékben - lehetünk szemtanúi szuburbanizációs folyamatok megindulásának.

Külön problémát jelent - és véleményünk szerint nagyon félreviheti a fövárosi urbanizációról kialakult történeti képet -, hogy a hazai kutatók munkáiban gyakran keveredik a szuburbanizáció és az agglomeráció fogalma. A német Wolf Gaebe modellje - az Izsák Éva (2003) által ismertetett módon - annyiban tér el a klasszikus szakaszolásoktól, hogy a városfejlődés oldaláról közelíti meg a szuburbanizációs szakaszt, ezért tagolása is másképp néz ki. A szuburbanizációnak három típusát különíti el annak alapján, hogy melyik funkció erősödik a városkörnyéki területen. Az első típus nála is a lakossági vagy lakóövezeti szuburbanizáció, de emellett két új lehetőséget is felmutat: az ipari szuburbanizációt, amely az ipari üzemek városkörnyékre történő települését jelenti és a tercier szektor szuburbanizációját, amikor a szolgáltató szektor teszi meg ugyanezt.

Amennyiben - helyesen - az ipari fejlődést tekintjük a városrobbanás vagy a klasszikus urbanizáció megindítójának, megkerülhetetlen, hogy a tyúk vagy a tojás dilemmájával is foglalkozzunk az urbanizáció és az agglomeráció kapcsolatában. A két fogalom pontos tisztázása, időbeni megjelenésének vizsgálata nélkülözhetetlen fontosságú, és meglátásunk szerint kiemelt jelentőséggel bír a történeti jellegủ városkörnyéki kutatások pontos értelmezésében. 
Az általánosan elterjedt felfogás szerint az agglomeráció ${ }^{3}$ a településegyüttesek igen kifejlett formája. Az agglomerációk kialakulását egy hosszabb folyamat, az agglomerálódás előzi meg, melyről Ehleiter (2007, 160.) így ír: „Az agglomeráció a területi fejlődés része, erőteljesebb kibontakozása a hazai településrendszer szerkezetében az 1950-es évek második felétől figyelhető meg. Az ipar fejlődése, az ipari termelés koncentrálódása és az annak nyomán bekövetkezett népességtömörülés és infrastruktúra-fejlesztés hatott az érintett térségekben fekvő települések tömörülésére, illetve a társadalmi-gazdasági és funkcionális-területi kapcsolataik különböző jellegű és intenzitású összefonódására." Ennek értelmében az agglomerálódás és az agglomeráció jellemzői a szuburbanizáció korai és késői szakaszának együttes jellemzőivel egyeznének meg. Az agglomerálódás a klasszikus urbanizáció következménye, az ipari koncentráció, a népességkoncentráció, majd az infrastruktúra-fejlesztés sorrendjében. ${ }^{4} \mathrm{E}$ sematikus megállapításokat cáfolják a fóváros és térségére vonatkozó vizsgálatok (Barta, Beluszky 1999), kimutatva, hogy agglomerálódás már a városrobbanás előtt, az 1850-es években is jellemző volt a fövárosban (Újpest, Albertfalva), és az azt követő évtizedekben - még mindig az ipari kibontakozást megelőzően - szintén jelen volt a fővárosban és környékén. Az elővárosok, telepek alkalmazotti, tisztviselői, kistermelői népességét semmiképpen sem lehet azonosítani a klasszikus urbanizáció népességnövekedésével, annak mértékével, összetételével, a gyáripari munkásság lakóhelyi koncentrációjával, életkörülményeivel.

Összességében, ha - legalábbis Budapest esetében - az urbanizáció kronológiáját kell megalkotnunk, a környezö területek egy részének agglomerálódása kezdődött legkorábban, amelyet - ettöl függetlenül - a fóváros klasszikus urbanizációja követ, ezt pedig a fơváros térségének különböző zónáiban eltérő időben és mértékben, de együttesen jelentkező (ipari) szuburbanizációs, majd agglomerációs folyamatai váltják fel. Leegyszerüsítve: egy kertvárosias jellegü tisztviselö- vagy nyaralótelep létrejötte korábbi ipari koncentráció hatása nélkül egyszerü agglomerálódás (Albertfalva), míg azt követően már szuburbán folyamatként (Királyerdő) értelmezhető a föváros és térségének egyes zónáiban.

Továbbá észre kell venni a különbséget: míg a klasszikus városrobbanásnak lényegében egyetlen motiváló tényezője van, az ipari koncentráció, és következményeként népességtömörülés alakul ki, addig az agglomerálódás folyamata más-más okok miatt is megindulhat; ezek közül talán a legjellemzőbb az iparosodás. A két fogalom értelmezési kerete tehát nem azonos: míg az urbanizáció a fejlődési tényezők oldaláról, addig az agglomeráció a településhálózat változásának oldaláról közelíti meg ugyanazt a folyamatot.

Mindezek alapján már megkísérelhetjük az urbanizációs folyamatok rekonstrukcióját Kis-Budapest környékén a 20. század első felében. Csatlakozva az evolúciós iskola föáramához, a föváros környezetében az urbanizációs folyamatok intenzitása alapján elkülönítünk egymástól egy közvetlen urbanizációs zónát (ahol az urbanizációs folyamatok a legintenzívebben érvényesülnek), egy tágabb ur- 
banizációs zónát (ahol az urbanizációs folyamatok az előbbinél gyengébben, de még kimutatható módon érvényesülnek) s végül az urbanizációs folyamatból kimaradó települések zónáját. Ezzel párhuzamosan - az urbanizációs folyamatok jellege alapján - beszélhetünk ipari övezetról, a munkás-, tisztviselö- és nyaralótelepek övezetéról, valamint a város mezögazdasági ellátóövezetébe tartozó településekről, de rámutathatunk bizonyos átmeneti típusok létére is.

- Az ipari övezet. Ha a különféle evolúciós iskolák sémáiban gondolkodunk, akkor azt kell mondanunk, hogy az „ipari övezet” (Berend T., Ránki 1961) kialakulása a klasszikus urbanizáció szakaszához kötődik, amely azonban Budapest esetében átlépte a központi város közigazgatási határait. Ezért a már korábban is létező, de felvirágzásukat egyértelműen a modern nagyiparnak köszönhető települések (pl. Újpest, Promontor/Budafok) mellett a századfordulón az ipari övezet olyan meghatározó települései nőttek ki a semmiből, mint Kispest (1883) vagy Erzsébetfalva/Pestszenterzsébet (1888). Noha e településeknek funkcionális értelemben már a két világháború között egyértelmü helyük lett volna Nagy-Budapest közigazgatási határain belül, a tényleges egyesítésre a korabeli várospolitika anomáliái miatt egészen 1950-ig kellett várni.

- A munkás-, tisztviseló- és nyaralótelepek. Az evolúciós iskola számos képviselője szerint a „tehetős rétegek kiköltözése a közvetlen vonzáskörzet még érintetlen zöldövezeteibe" (Tózsa 2011, 76.) egyértelmüen szuburbanizációs jelenség. Enyedi György azonban úgy véli, hogy a szuburbanizáció Kelet-Közép-Európában csak az 1970-es években jelent meg, s ha ez így van, akkor a 20. század első felében meglehetősen nehéz az efféle Budapest környéki telepek értelmezése. A látszólagos ellentmondás feloldásához az adhatja a kulcsot, hogy a budapestiek 20. század első felében tapasztalható kiköltözési hulláma aligha illeszthető be a klasszikus szuburbanizációs sémákba. A tehetős rétegek legfeljebb a nyaralótelepeken jelenhettek meg, míg a munkás- és tisztviselőtelepeket inkább az alsó középrétegek választották lakóhelyül. A túlsúlyban lévő munkás- és tisztviselőtelepek kialakulásában tehát nem elsősorban a tehetős rétegek érintetlen zöldövezetbe vágyódása, sokkal inkább a fóvárosi telekpolitika akkori sajátosságai játszották a fő szerepet. Már Lord Albert (1901) felhívta rá a figyelmet, hogy a fővárosi építési övezetek telekminimumai túlságosan magasak családi házak építéséhez, legfeljebb nagyméretű bérkaszárnyákra alkalmasak. Összességében leszögezhető: az alsó középrétegek számára - ha nem kívántak bérkaszárnyába vonulni a vizsgált korszakban ritkán maradt más lehetőség, mint a közigazgatási határokon túlra való költözés.

- A város mezögazdasági ellátóövezete. A Budapest környéki urbanizálódó térség különleges területe, ahol a városiasodás kevéssé direkt, bonyolultabb módon, tehát nem a városból kiköltözőkkel együtt ment végbe. Bár Pest-Buda a 19. század második felében megkezdődő rohamos fejlődése 
előtt jóval is piaca volt a szomszédos települések agrárterményeinek, a dualista korszakban minőségi ugrás következett be: Budapest egyre csökkenő mezőgazdasági területein lényegében már egyáltalán nem tudta megtermelni a lakosság számára szükséges terményeket, s a városi életmód, illetve az életszínvonal emelkedése miatt egyre nagyobb igény lett a különböző zöldség- és gyümölcsfélékre (Bodor 1934; Boross 1956; Csoma 1998). Mindez a főváros környékén egyre jelentősebb belterjes mezőgazdasági kultúrához vezetett, amely a mind gyakoribb piacozásokkal, új terményszerkezet és művelési módok meghonosodásával alapjaiban formálta át a környék agrártársadalmát.

- Az átmeneti típusok. Végül meg kell jegyeznünk, hogy az imént vázolt urbanizációs típusok semmi esetre sem kizárólagosak. Önálló és tiszta formában leginkább az ipari övezet jelenik meg, ahol a dinamikus nagyipari fejlődés és az ezzel együtt járó rohamos betelepülés igen hamar és egyértelműen a maga képére formálta a hagyományos struktúrákat. A munkás-, tisztviselő- és nyaralótelepek, valamint a mezőgazdasági ellátóövezet településein azonban ez már nem mindig igaz. A munkás-, tisztviselő- és nyaralótelepek egy része ugyan hamar önállósult (mint Rákoskeresztúrtól Rákosliget 1907-ben, Rákoshegy pedig 1921-ben), s ezek övezetbe sorolása a leválás után nem jelenthet gondot. De mivel egy idő múlva - hogy mikorra s milyen intenzitással, az természetesen településenként változott - az őslakosok és a betelepülők közötti szegregáció az egyéb településeken is egyre inkább az integráció irányába mozdult el, az együttélés az urbanizáció által érintett településtípusok újabb, átmeneti típusait hozta létre (Buskó 2001).

\section{A vizsgálat menete}

Tanulmányunk a jelenlegi budapesti agglomeráció ${ }^{5}$ kialakulását nyomon követő kutatás első lépcsője, ezért adatbázisunkat az összes érintett településre építettük ki. Ami a vizsgálat kezdőpontját illeti, természetesen tudatában vagyunk annak, hogy urbanizációs folyamatok már a 19. század harmadik harmadában kimutathatók a föváros környékén. Vörös Károly (1978) kutatásai elsősorban az ÚjpestRákospalota komplexum korai urbanizálódására hívják fel a figyelmet (Újpest népessége már a századfordulón elérte a 42 ezer főt), de - ha csekélyebb mértékben is - hasonló tendenciák tapasztalhatók a délen kialakult három telepen: Erzsébetfalván, Kispesten és Pestszentlőrincen. A statisztikai forrásanyag szűkössége a 19. század második felében azonban nem tett volna lehetővé egy részletes, számszerűsítésen alapuló vizsgálatot. Ezért vizsgálatunk kezdetéul - mivel adatforrásainkat ettől kezdve ítéltük megfelelő részletességünek - az 1901-1910 közötti időszakot (a természetes szaporodás és a vándorlási különbözet esetében), vala- 
mint az 1910. december 31-i eszmei időpontú cenzust (a többi mutató esetében) választottuk. ${ }^{6}$

Néhány esetben speciális problémát jelentett a népszámlálási kötetekben szereplő települések adatbázisunkba illesztése. A cenzus felvételének településállománya ugyanis néhol eltér a jelenlegitől. A legjelentősebb különbséget Nagy-Budapest létrehozása okozta, 1950. január 1-jétől ugyanis 23, korábban önálló település vált a főváros részévé. Ezeket a településeket az 1949-es közigazgatási állapot szerint szerepeltettük adatbázisunkban. Az egyéb településösszevonások esetében viszont igyekeztünk a jelenlegi közigazgatási beosztáshoz igazodni: így például Őrszentmiklós és Vácbottyán adatait már az 1910 és 1941 közötti időszakban az akkor még nem létező őrbottyán név alatt vontuk össze. Nagyobb gondot jelentettek a korszakunkban igen gyakori településönállósulások (pl. Pestszentlőrinc csak 1910-től önálló település, előtte Kispesthez tartozott). Az önállósulást követő első cenzus idején - mivel a természetes szaporodás és a vándorlási különbözet adatai a megelöző időszakban még nem állnak rendelkezésünkre - az érintett településeket még csupán együttesen (példánkban: „Kispest és Pestszentlőrinc” alakban) szerepeltethettük adatbázisunkban. További nehézséget jelentett Délegyháza, hiszen ez a jelenleg a budapesti agglomeráció részét képező település 1950-ben önállósult a Bugyihoz tartozó Alsódélegyháza, valamint a Dabashoz tartozó Felsődélegyháza községrészekből. Ezért itt a „Bugyi, Dabas és Délegyháza” megoldást alkalmaztuk. A vizsgálat eredményeinek bemutatásánál így néhol - különösen, ha vizsgálatunk legkisebb egységei nem önálló települések, hanem településcsoportok - a „település” helyett a „vizsgálati egység” elnevezést fogjuk használni.

Ezt követően nézzük, melyek azok a változók, melyek az 1910-es, 1920-as, 1930-as és 1941-es népszámlálásokban egyaránt rendelkezésünkre állnak, és hipotézisünk szerint - modernizációs tendenciákra utalhatnak. A következőkről lehet szó:

- Természetes szaporodás: mivel a természetes szaporodás értékeinek csökkenése a modernizáció egyik indikátora, sejtésünk szerint azokon a településeken, ahol a város hatása erőteljesebb, a természetes szaporodás értékei csökkenni fognak. Az évenkénti ingadozások hatásának kiszürésére vizsgálatunkban a természetes szaporodás értékeinek tízéves átlagát (tehát pl. az 1910-es év esetében az 1901-1910-es időszak átlagát) vettük figyelembe.

- Vándorlási különbözet: a nagymértékű bevándorlás miatt az urbanizálódó településeken a vándorlási különbözet értékei magasabbak lesznek. Az évenkénti ingadozások hatásának kiszürésére a vándorlási különbözet esetében is a tízéves átlagértékeket vettük figyelembe.

- Mezögazdasági keresők aránya:? az ipari övezet településein, valamint a munkás-, tisztviselő- és nyaralótelepeken a mezőgazdasági foglalkoztatottak aránya nyilvánvalóan roppant csekély lesz. Ez az összefüggés az átmeneti típusok településein kevésbé, a mezőgazdasági ellátóövezet településein pedig csak igen kis mértékben fog érvényesülni. 
- Írni-olvasni tudók aránya: korszakunkban az analfabetizmus még nem szorult vissza annyira, hogy az írni-olvasni tudók arányából ne lehetne következtetéseket levonni a népesség általános műveltségi állapotára nézve. Sejtésünk szerint azokon a településeken, ahol az urbanizáció előrébb tart, az írni-olvasni tudók aránya is növekedni fog.

- Kö- és téglaházak aránya: az urbanizációnak nyilvánvalóan tükröződnie kell a település általános képében is. Ezért sejtésünk szerint a vályogból és sárból épített, valamint a különféle vegyes építésủ házak helyét az urbanizáció előrehaladásával egyre inkább át fogják venni a kő- és téglaépítésü házak.

Ha a korabeli magyarországi állapotokkal összehasonlítva egyenként vesszük szemügyre az adatbázis változóinak 1910 és 1941 közötti alakulását (1. táblázat), annyit feltétlenül megállapíthatunk, hogy valamiféle modernizációs folyamat lejátszódott a vizsgálat kezdő- és végpontja között.

A természetes szaporodás és a mezőgazdasági keresők arányának csökkenése, valamint az írni-olvasni tudók és a kő- és téglaépítésű házak arányának növekedése a modernizáció egyértelmű előrehaladására utal. $S$ tulajdonképpen az urbanizációs folyamat meghatározó indikátorának tekinthető vándorlási különbözettel is ez a helyzet: az 1900-1910-es időszakhoz képest ugyan az 1930-1941-es időszakban kissé alacsonyabb a vándorlási különbözet értéke, de a bevándorlási többlet még ekkor is jelentős maradt. Ha pedig hozzátesszük, hogy 1930 és 1941 között 160726 fővel nőtt az általunk vizsgált terület össznépessége (ugyanez az érték 1900 és 1910 között a jóval magasabb természetes szaporodás mellett is csak 141266 fö volt), akkor a tendencia még egyértelműbb.

$\mathrm{Az}$ általában véve vett modernizáció igazolásával azonban még nem egyértelmü, mennyiben köszönhető ez a fejlődés Budapest közelségének, az urbanizációs folyamatoknak. Ha sikerül kimutatni a modernizációs folyamatok

1. táblázat: Modernizációs mutatók a jelenlegi budapesti agglomerációban és Magyarországon (1910-1941)

Indicators of modernisation in the recent Budapest Metropolitan Area and in Hungary (1910-1941)

\begin{tabular}{lccccc}
\hline Területegység & $\begin{array}{c}\text { A természetes } \\
\text { szaporodás } \\
\text { tízéves átlaga } \\
(\%)\end{array}$ & $\begin{array}{c}\text { A vándorlási } \\
\text { künbózes átlaga } \\
(\%)\end{array}$ & $\begin{array}{c}\text { A mezó- } \\
\text { gazdasági } \\
\text { keresók } \\
\text { aránya (\%) }\end{array}$ & $\begin{array}{c}\text { Irni-olvasni } \\
\text { tudók a } 6 \\
\text { éven felüli } \\
\text { népességból } \\
(\%)\end{array}$ & $\begin{array}{c}\text { épitésü tégla- } \\
\text { aránya (\%) }\end{array}$ \\
\hline Budapesti agglomeráció, 1910 & 17,8 & 17,2 & 51,0 & 83,5 & 34,1 \\
Magyarország, 1910* & 12,2 & $-1,1$ & 57,2 & 82,8 & 22,1 \\
\hline Budapesti agglomeráció, 1941 & 5,8 & 14,2 & 36,7 & 94,6 & 62,2 \\
Magyarország, 1941 & 7,3 & 0,8 & 48,9 & 92,4 & 27,7 \\
\hline
\end{tabular}

* A kö- és téglaépítésü házak esetében a Trianon előtti területekre vonatkozó adatok. A többi mutatónál a jelenlegi országterületre vonatkoztatott adatok.

Adatok forrása: KSH. 
területi egyenlőtlenségét az általunk vizsgált területen, valamint ezeket az egyenlőtlenségeket sikeresen összefüggésbe tudjuk hozni Budapest hatásával, akkor az urbanizáció 1910 és 1941 közötti megjelenésének hipotézise is igazolható. Ehhez azonban szükségünk lesz a vizsgált változók eddigieknél mélyebb elemzésére. De hogyan hajtsunk végre egy ilyen elemzést?

Mindenekelőtt feltételezzük, hogy létezik olyan változó, amellyel kimutathatjuk az adatbázisunk részét képező települések modernizációs folyamatait. Mivel ilyen modernizációs változót természetszerűleg egyetlen korabeli népszámlálás sem közöl, csakis egy olyan változóról lehet szó, amelyet valamilyen többváltozós matematikai-statisztikai eljárással hozunk létre a népszámlálási adatforrásaink változóiból. Ezt a feladatot az egyik leginkább elterjedt adatredukciós eljárással, a főkomponens-elemzéssel hajtottuk végre. Anélkül, hogy belemennénk az eljárás matematikai részleteibe, csupán annyit jegyezzünk meg, hogy egy főkomponens-elemzést általában akkor szoktak sikeresnek tekinteni, ha

- az egyes változók elég szorosan - megegyezés szerint legalább 0,25-ös kommunalitásértékkel - illeszkednek a fökomponenshez,

- a fókomponens az egyes változók heterogenitásának elég nagy hányadát - megegyezés szerint legalább 50\%-át - megőrzi.

Mindezek ismeretében a vizsgált időszakra vonatkozó főkomponens-elemzések eredményei a következők (2. táblázat). Az általunk választott modernizációs változók két kivételtől eltekintve kielégítik a fenti követelményeket. 1910-ben az írni-olvasni tudók aránya, 1920-ban pedig a természetes szaporodás illeszkedett kevéssé főkomponensünkhöz. Ezeket a változókat tehát ki kellett hagynunk az 1910-es, illetve az 1920-as népszámlálás adatain alapuló főkomponensünkből. A megőrzött heterogenitás így minden esetben meghaladja az 50\%-ot, vagyis biztonsággal továbbléphetünk az urbanizációs folyamat igazolása felé.

2. táblázat: A főkomponens-elemzés eredményei Results of the principal component analysis

\begin{tabular}{lcccc}
\hline \multicolumn{1}{c}{ Mutató } & 1910 & 1920 & 1930 & 1941 \\
\hline A természetes szaporodás kommunalitásértéke & 0,413 & - & 0,469 & 0,582 \\
(komponensmátrix-érték) & $(0,643)$ & & $(-0,685)$ & $(-0,763)$ \\
A vándorlási különbözet kommunalitásértéke & 0,791 & 0,517 & 0,554 & 0,524 \\
(komponensmátrix-érték) & $(0,889)$ & $(0,719)$ & $(0,745)$ & $(0,724)$ \\
A mezőgazdasági keresők arányának kommunalitásértéke & 0,737 & 0,805 & 0,72 & 0,765 \\
(komponensmátrix-érték) & $(-0,858)$ & $(-0,897)$ & $(-0,849)$ & $(-0,874)$ \\
Az írni-olvasni tudók arányának kommunalitásértéke & - & 0,284 & 0,5 & 0,385 \\
(komponensmátrix-érték) & & $(0,533)$ & $(0,707)$ & $(0,621)$ \\
A kő- és téglaházak arányának kommunalitásértéke & 0,442 & 0,526 & 0,704 & 0,727 \\
(komponensmátrix-érték) & $(0,665)$ & $(0,725)$ & $(0,839)$ & $(0,852)$ \\
\hline Megőrzött heterogenitás & $59,56 \%$ & $53,29 \%$ & $58,96 \%$ & $59,66 \%$ \\
\hline
\end{tabular}

Adatok forrása: KSH. 
Ezzel kapcsolatosan még egy érdekességre szükséges felhívnunk a figyelmet. 1910-ben a természetes szaporodás 0,413-as kommunalitásértéke mellett szintén pozitív komponensmátrix-érték ${ }^{8}$ szerepel. Ez annyit jelent, hogy az 1900 és 1910 közötti időszakban - hipotézisünkkel és a későbbi eredményekkel ellentétben - a természetes szaporodás és a modernizáció között még pozitív irányú kapcsolat állt fenn. Ez a meglepőnek tűnő eredmény véleményünk szerint azzal magyarázható, hogy az 1900 és 1910 közötti időszakban a természetes szaporodás értékeit elsősorban a modernizáció által érintett településekre kiköltöző fiatalabb korosztály magasabb termékenységi mutatói határozták meg, nem pedig a hipotézisben jelzett általános modernizációs tendenciák.

Az urbanizációs folyamat igazolása a főkomponensértékek vizsgálatával lehetséges. Ezek standardizált formában adják meg a „modernizációs változó” egyes településekhez rendelt értékeit, a modernizációs folyamatok által leginkább érintett településektől (legmagasabb értékek) egészen a legkevésbé érintettekig (legalacsonyabb értékek). Ha az 1910-es és 1941-es főkomponensértékek maximum-, és minimumértékeit hasonlítjuk össze (1910-es maximum: 2,7149, minimum: -1,61971; 1941-es maximum: 2,27502, minimum: -2,32387), akkor is nyilvánvaló, hogy a korszakban a modernizáció által leginkább és legkevésbé érintett települések különbsége kissé nőtt. Ha ehhez hozzátesszük, hogy az 1. táblázat alapján a korszakban a változások inkább a modernizáció irányába hatottak, akkor levonható a következtetés: az 1910 és 1941 közötti időszakban Budapest környékén a modernizáció hatására differenciálódott a településállomány. Így viszont már el is jutottunk a vizsgálat legfontosabb kérdéséhez: mennyiben köszönhető ez a differenciálódás Budapest hatásának, vagyis mennyiben tehető egyenlőségjel az általunk vizsgált területen a modernizáció és az urbanizáció közé?

A válaszhoz itt és most csak annyit állíthatunk, hogy a fővároshoz való közelség és a modernizáció foka között szoros összefüggés mutatható ki. Elegendő ehhez egyetlen pillantást vetni a főváros közvetlen közelében fekvő, 1950-ben Nagy-Budapesthez csatolt 23 település főkomponensértékeire. Mivel az általunk vizsgált korszakban egyetlen esetben sem fordult elő, hogy egy 1950-ben Nagy-Budapesthez csatolt településhez a térség átlagánál gyengébb modernizációs érték tartozzék, az urbanizáció és az átlag feletti modernizáció - legalábbis korszakunkban és térségünkben - nagyjából-egészében ugyanazt a településcsoportot érintette. Ezért a modernizációs változókat a továbbiakban - urbanizációs változók néven - az urbanizációs zónák és az urbanizációs övezetek meghatározására fogjuk felhasználni.

\section{Az urbanizációs zónák}

Első feladatunk meghatározni az urbanizáció fokának zónáit Budapest környékén az 1910 és 1941 közötti időszakban. A főkomponensértékek kiszámítása után könnyedén kiválogathatók a pozitív főkomponensértékekkel rendelkező 
települések, vagyis azok, amelyekben az urbanizációs tendenciák már észrevehetően (a térség átlagánál erőteljesebben) jelentkeznek. Az így lehatárolt urbanizálódó térséget - hogy vizsgálataink eredményét könnyebben összhangba lehessen hozni az evolúciós iskola fỏáramával - egy közvetlen és egy tágabb urbanizációs zónára osztottuk tovább. Ehhez az egyes népszámlálási évek főkomponenseinek terjedelmét három-három egyenlő osztályközre bontottuk, majd a felső harmadba tartozó településeket azonosítottuk a közvetlen urbanizációs zónával. A tágabb urbanizációs zónát a felső harmadból kimaradó, de még pozitív főkomponensértékekkel jellemezhető települések csoportja jelöli ki. Az így kapott eredmények már ebben a formájukban is sokat elárulnak a Budapest környéki urbanizálódó térség kiterjedéséről és fejlődéséről 1910 és 1941 között (3. táblázat, 1. ábra).

Legszembetűnőbb, hogy korszakunkban az urbanizációs zónák és az urbanizációs folyamatból kimaradó települések arányaiban nem tapasztalható különösebb elmozdulás. Néhány kivételtől eltekintve a korszakunk elején az urbanizálódó térséghez tartozó települések korszakunk végére is az urbanizálódó térség részei maradtak, mint ahogy az urbanizálódó térségen kívülről is csak ritkán lehetett azon belülre kerülni. ${ }^{9}$ Jelentős elmozdulás csak a közvetlen és a tágabb urbanizációs zónák között tapasztalható. A belső maghoz tartozó települések számának majdnem két és félszeres növekedése azonban nem járt együtt a tágabb urbanizációs zónához tartozó települések számának hasonló mértékủ csökkenésével, ami arra utal, hogy az elmozdulás jó része a korábban is a közvetlen urbanizációs zónához tartozó települések egyes részeinek önállósulásával magyarázható. Így az 1910-es Cinkota, Mátyásföld és Sashalom vizsgálati egységből 1941-re Sashalom, a Kispest és Pestszentlőrinc vizsgálati egységből Pestszentlőrinc, a Rákospalota és Pestújhely vizsgálati egységből pedig Pestújhely önállósult. Hasonló a helyzet azokkal a valószínűleg már korábban is erőteljesen urbanizálódó településrészekkel, amelyek önállósulva a már 1910ben a tágabb urbanizációs zónába tartozó településekből a közvetlen urbanizációs zóna önálló településeivé váltak (Csömörből Rákosszentmihály; Rákoskeresztúrból Rákosliget és Rákoshegy; a Sződ, Göd, Csörög és Sződliget vizsgálati egységből Göd). Mindebből az következik, hogy 1910 és 1941 között csupán

3. táblázat: Az urbanizációs folyamatok intenzitása a jelenlegi budapesti agglomeráció településein (1910-1941)

Intensity of urbanisation processes in the recent Budapest Metropolitan Area (1910-1941)

\begin{tabular}{cccc}
\hline Év & $\begin{array}{c}\text { A közvetlen urbanizációs zónához } \\
\text { tartozó települések száma }\end{array}$ & $\begin{array}{c}\text { A tágabb urbanizációs zónához } \\
\text { tartozó települések száma }\end{array}$ & $\begin{array}{c}\text { Az urbanizációból kimaradó } \\
\text { települések száma }\end{array}$ \\
\hline 1910 & 9 & 24 & 49 \\
1920 & 16 & 23 & 47 \\
1930 & 17 & 23 & 48 \\
1941 & 22 & 21 & 46 \\
\hline
\end{tabular}

Adatok forrása: KSH. 
1. ábra: Az urbanizációs folyamatok intenzitása a jelenlegi budapesti agglomeráció településein (1910-1941)

Intensity of urbanisation processes in the recent Budapest Metropolitan Area (1910-1941)

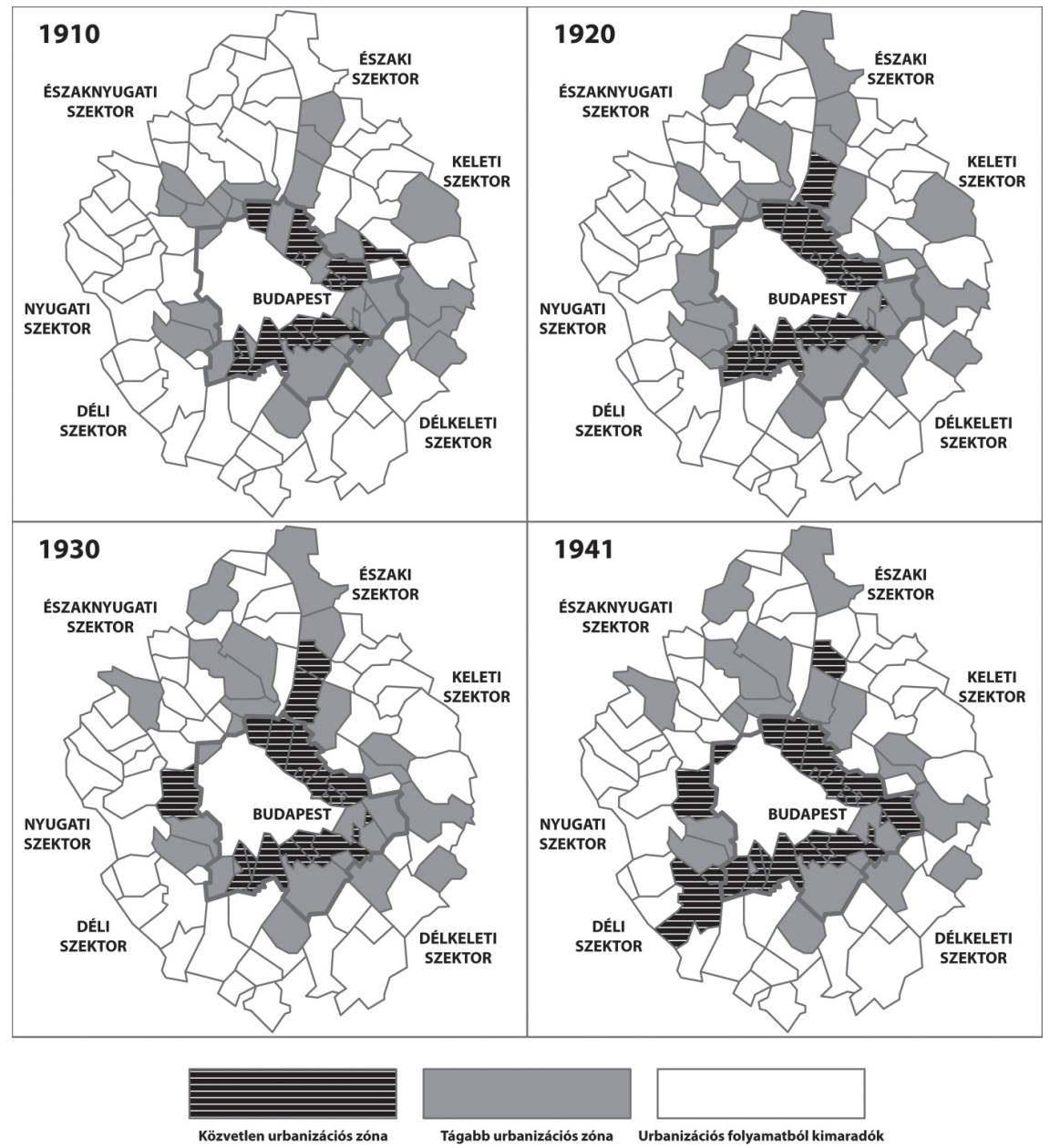

6 település - Albertfalva, Budakeszi, Nagytétény, Pesthidegkút, Rákoscsaba és Ujpest - emelkedett a tágabb urbanizációs zónából a közvetlen urbanizációs zónába. Végül említsük meg, hogy előfordul a közvetlen urbanizációs zónából a tágabb urbanizációs zónába, illetve a tágabb urbanizációs zónából az urbanizációból kimaradó települések közé történő visszasorolódás is. A jelenség mögött a legtöbb esetben természetesen nem a tényleges „visszafejlődés” állhat, hanem az adatbázis bizonyos sajátosságai. A Sződ, Csörög és Sződliget vizsgálati egység visszasorolódása mögött például az igen kedvező urbanizációs mutatókkal jellemezhető Alsógöd és Felsőgöd településrészek 1921-es kiválása áll. Más esetekben pedig valószínúleg abban keresendő a jelenség oka, hogy a főkompo- 
nensértékek nem az urbanizáció abszolút értékeire, hanem az egyes települések egymáshoz viszonyított urbanizációs szintjére mutatnak rá. Vagyis egy urbanizálódó település is visszasorolódhat abban az esetben, ha fejlődése szerényebb a budapesti agglomeráció egyéb, nála dinamikusabban fejlődő településeihez képest. Ezen urbanizációs mutatók változását viszont egyetlen módon lehetséges igazolni vagy cáfolni - ez pedig kutatásunk második szakaszának a feladata -, a helytörténeti, helyi információk részletes feldolgozásával és a területi fejlődés minél pontosabb reprodukálásával.

Ha tehát az 1910 és 1941 közötti időszakban Budapest környékén a településállomány a modernizáció hatására differenciálódott, akkor hozzátehetjük: a differenciálódásért nem elsősorban az urbanizációs zónák valamelyikébe történó elörelépés, hanem sokkal inkább a közvetlen, illetve tágabb urbanizációs zónák valamelyikébe tartozó településeknek az urbanizációból kimaradó településekhez viszonyitott erőteljesebb modernizációja a felelös.

\section{Az urbanizációs övezetek}

Az urbanizáció jellege alapján lehatárolható övezetek besorolási kritériumait a 4. táblázatban foglaljuk össze. A következőkben e kritériumok alapján mutatjuk be a Budapest környéki urbanizálódó térség alakulását az általunk vizsgált korszakban. A jobb követhetőség érdekében a budapesti agglomerációt a ma elterjedt tagolás szerint északi, keleti, délkeleti, déli, nyugati és északnyugati szektorra bontjuk, kiegészítve azokat a ma már Nagy-Budapest részét képező települések csoportjával (2. ábra).

Az 1950-ben Nagy-Budapesthez csatolt települések a közvetlen urbanizációs zóna magját képezik. 1910-ben a 9, közvetlen urbanizációs zónába tartozó vizsgá-

4. táblázat: Az egyes urbanizációs övezetek kritériumai

Criteria of urbanisation zones

\begin{tabular}{|c|c|c|c|c|c|}
\hline Övezet & $\begin{array}{c}\text { A mezőgazdasági } \\
\text { foglalkoztatottak } \\
\text { aránya }\end{array}$ & $\begin{array}{c}\text { Az ipari } \\
\text { foglalkoz- } \\
\text { tatottak } \\
\text { aránya }\end{array}$ & $\begin{array}{c}\text { A tercier } \\
\text { szektorban } \\
\text { foglalkoz- } \\
\text { tatottak } \\
\text { aránya }\end{array}$ & $\begin{array}{l}\text { A } 20 \text { fönél több } \\
\text { foglalkoztatottal } \\
\text { rendelkező } \\
\text { iparvállalatok } \\
\text { száma* }\end{array}$ & $\begin{array}{l}\text { Az urbanizációs } \\
\text { zónába tartozás }\end{array}$ \\
\hline Ipari övezet & $20 \%$ alatt & $50 \%$ felett & - & Legalább 1 & \multirow{4}{*}{$\begin{array}{c}\text { Legalább a } \\
\text { tágabb } \\
\text { urbanizációs } \\
\text { zóna része }\end{array}$} \\
\hline $\begin{array}{l}\text { Munkás-, tisztviselo”- } \\
\text { vagy nyaralótelepek }\end{array}$ & $20 \%$ alatt & \multicolumn{2}{|c|}{ Együtt: legalább 50\% } & Nincs & \\
\hline $\begin{array}{l}\text { Mezőgazdasági } \\
\text { ellátóöövezet }\end{array}$ & $50 \%$ felett & - & - & - & \\
\hline Átmeneti övezet & $\begin{array}{c}20 \% \text { és } 50 \% \\
\text { között }\end{array}$ & - & - & - & \\
\hline
\end{tabular}

\footnotetext{
* Az 1941-es népszámlálás esetében - adathiány miatt - az 1930-as népszámlálás eredményeit használtuk.
} 
2. ábra: Az urbanizációs folyamatok jellege a jelenlegi budapesti agglomeráció településein (1910-1941)

Characteristics of urbanisation processes in the recent Budapest Metropolitan Area (1910-1941)

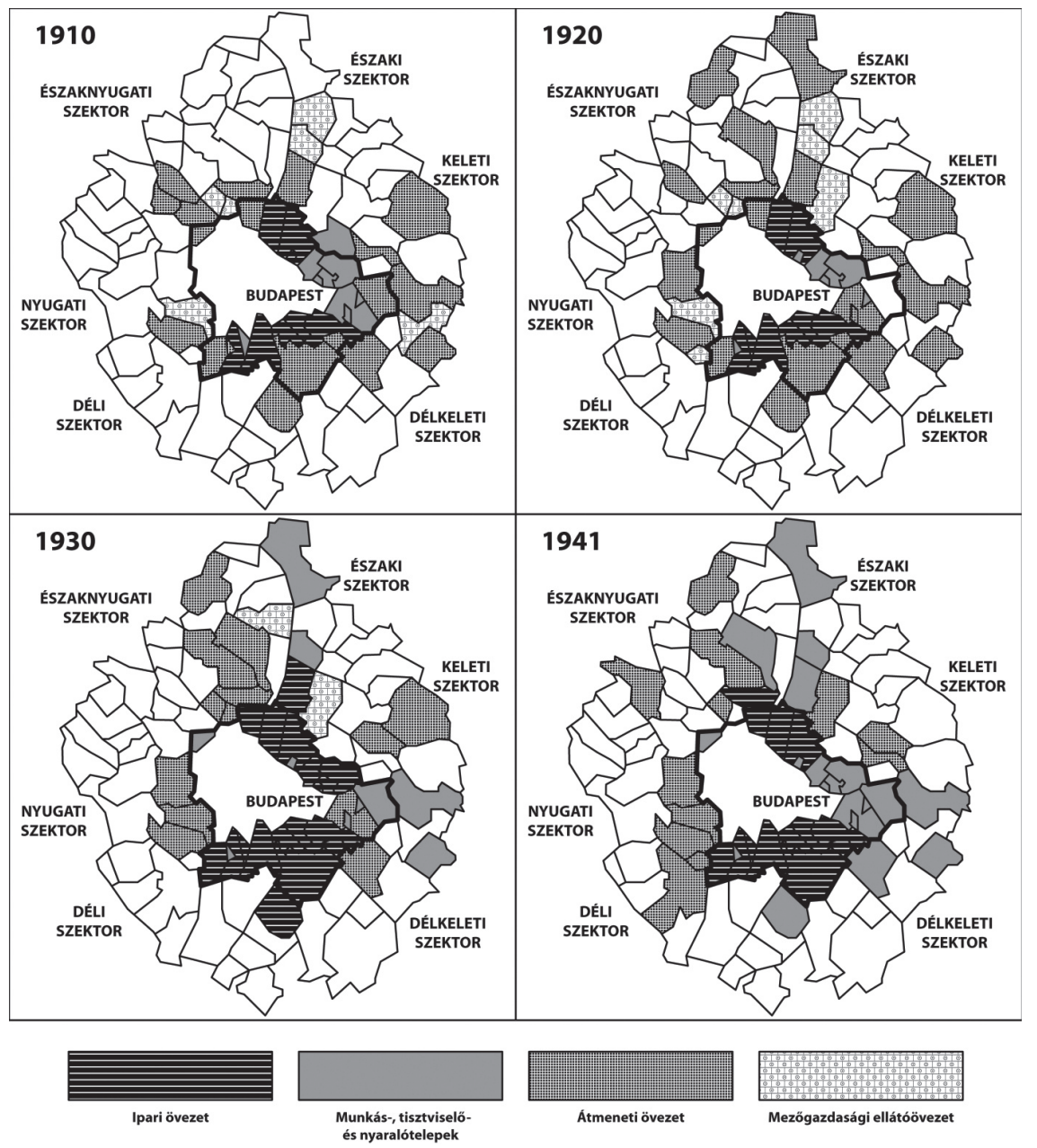

lati egység közül 8 ebbe a szektorba tartozik, de még 1941-ben is ennek a szektornak képezi részét a közvetlen urbanizációs zóna 22 vizsgálati egységének döntő többsége (szám szerint 18). Az urbanizációs övezetek közül leginkább az ipari övezetben figyelhető meg az 1950-ben Nagy-Budapesthez csatolt települések dominanciája. 1910-ben és 1920-ban az ipari övezethez csupán ennek a szektornak a települései tartoztak (köztük a legjelentősebb urbanizálódó települések, mint Erzsébetfalva/Pestszenterzsébet, Újpest, valamint Kispest és Pestszentlőrinc). Az ipari övezet csak 1930-ra egészült ki a Nagy-Budapesten kívüli Dunakeszi és Alag vizsgálati egységgel, valamint Dunaharasztival. A szektor 
másik jelentős övezetét a munkás-, tisztviselö- és nyaralótelepek jelentik. 1941-re az ide sorolható 19 vizsgálati egység többsége (szám szerint 10) még mindig az 1950-ben Nagy-Budapesthez csatolt települések szektorának képezi részét. Az agrárfoglalkozásúak egyértelmü dominanciájával jellemezhető mezőgazdasági ellátóövezet nem található meg a szektorban, az átmeneti típusba tartozó vizsgálati egységek viszont korszakunk elején még jelen vannak. Nagy-Budapest e mérsékelten vidéki jellegü települései közül 1910-ben öt vizsgálati egységet emelhetünk ki (Békásmegyer, Budatétény, Nagytétény, Rákoscsaba, Soroksár és Pestszentimre), de az agrárnépesség csökkenése miatt 1941-re már valamennyiüket az ipari övezetben vagy a munkás-, tisztviselö- és nyaralótelepek övezetében találjuk.

Az északi szektorra az erőteljesebb urbanizációs folyamatokkal jellemezhető Duna bal part és a Dunától távolabb eső, periferikus helyzetben lévő települések kettőssége nyomja rá a bélyegét. A Duna menti tengely legjelentősebb települései az 1921-ben Sződ, Csörög és Sződliget vizsgálati egységből önállósuló, de 1970-ig még Alsógöd és Felsőgöd néven létező Göd (1930-tól a közvetlen urbanizációs zóna részét képezi), valamint az 1930-ban a közvetlen, 1941-ben a tágabb urbanizációs zóna részét képező Dunakeszi és Alag vizsgálati egység. A szektor legnépesebb települése, Vác korszakunkban csak a tágabb urbanizációs zóna szintjéig tudott felemelkedni. ${ }^{10}$ Ami az egyes övezeteket illeti, Göd 1941-ben már egyértelműen tisztviselőtelep, Dunakeszi és Alag az agrárfoglalkoztatottak folyamatos csökkenése miatt 1930-re az ipari övezethez csatlakozik, majd 1941-re - az ipari foglalkoztatottak háttérbe szorulása miatt - munkások és tisztviselők által vegyesen lakott teleppé válik. Vác a tágabb urbanizációs zónában való 1920-as feltűnése után szintén a munkás-, tisztviselő- és nyaralótelepek jellegzetességeit mutatja. A „hátországban" a Budapest környéki agrárkultúra egyik fellegvárának tekinthető Fót érdemel figyelmet, amely 1920 után már egyértelműen a mezőgazdasági ellátóövezet egyik szép - igaz, a szektorban szigetszerü - példája.

A keleti szektorban Kistarcsa némileg meglepő - s elsősorban az 1900 és 1910 közötti évek magas vándorlási különbözetével magyarázható - 1910-es eredményét kivéve egyáltalán nincs jelen a közvetlen urbanizációs zóna. A tágabb urbanizációs zónához tartozó néhány település (az 1941-ben a tágabb urbanizációs zónából kikerülő Gödöllo", valamint Kerepes és Pécel) magas agrárnépessége miatt általában az átmeneti zóna részét képezte korszakunkban, egyedül Pécelen fedezhetjük fel 1941-re a tisztviselőtelepek irányába történő elmozdulást.

A délkeleti szektor szintén gyengén fejlett térség, ahol még a tágabb urbanizációs zónába való betagozódás is csak két településnek (Gyömrő és Vecsés) sikerült. A kezdetben még az átmeneti zóna részét képező települések az agrárfoglalkoztatottak arányának lassú csökkenése miatt 1941-re a munkás-, tisztviselő- és nyaralótelepek övezetének jellegzetességeit veszik fel. Az egyéb települések közül legfeljebb az a Maglód érdemes figyelmünkre, amely 1910ben még a mezőgazdasági ellátóövezet tagja, de később különféle urbanizációs mutatóinak kedvezőtlen alakulásával visszasüllyedt az urbanizációból kimaradó települések kategóriájába. 
A déli szektor nagy kiterjedésének köszönhetően némileg összetettebb képet mutat. Az itt található vizsgálati egységek legnagyobb hányada a délkeleti szektorhoz hasonló, periferikus helyzetű és az urbanizációs folyamatból teljességgel kimaradó település. A legfontosabb kivétel a Nagy-Budapesttől délre elhelyezkedő Dunaharaszti, amely már 1910-ben is része a tágabb urbanizációs zónának, s végigjárja az átmeneti övezettől $(1910,1920)$ az ipari övezeten át (1930) a munkás-, tisztviselő- és nyaralótelepek (1941) felé tartó fejlődési folyamatot. A másik fontos település, a déli szektor északkeleti csücskében található Diósd 1941-ig hol a tágabb urbanizációs zónán kívül (1910, 1930), hol azon belül (1920) található, hogy azután 1941-re - 1930-ban egyébként még elég csekély, mindössze 1047 fös népességének megkétszereződésével - a közvetlen urbanizációs zónában találja magát. Jelentős agrárnépessége miatt azonban még ekkor is csak az átmeneti övezetben tudjuk elhelyezni. Végül emlékezzünk meg a későbbiekben a budapesti agglomeráció egyik legjelentősebb településévé váló Érdről, amelynek karrierje a korszak vége felé kezdődött. 1941 előtt még az urbanizációs folyamatból kimaradó települések csendes életét élte, de 1930 és 1941 között népessége a nagyarányú betelepülések révén 5693 főről 13062 före nőtt, ami elegendő volt ahhoz, hogy a közvetlen urbanizációs zóna átmeneti övezetébe lépjen elöre.

A nyugati szektor Budai-hegység völgyeiben megbújó települései általában kimaradtak korszakunk urbanizációs folyamataiból. A teljes korszakban csupán Budaörs és Törökbálint volt képes betagozódni legalább a tágabb urbanizációs zónába. Közülük Budaörs 1910-ben és 1920-ban a mezőgazdasági ellátóövezet, 1930-tól pedig - az agrárfoglalkoztatottak arányának csökkenése miatt - az átmeneti övezet részét képezi, míg Törökbálint mindvégig az átmeneti övezetbe tartozik. A szektor legjelentősebb karriert befutó települése Budakeszi, a jelentős számú betelepülő miatt 1930-ban és 1941-ben már a közvetlen urbanizációs zóna része, az agrárfoglalkoztatott őslakosok miatt csak az átmeneti övezet részeként.

Végül essen pár szó az igen nagy kiterjedésű északnyugati szektorról is. Voltaképpen nem is nevezhetjük egységes szektornak, hiszen két térszerkezeti tengelyt, a Pilisvörösvári-árkot és a Duna jobb partot (valamint a kettő közötti, periferikus helyzetben lévő településeket) foglalja magában. A szektorhoz tartozó települések egyetlen esetben sem voltak képesek felemelkedni a közvetlen urbanizációs zónába. Ami a tágabb urbanizációs zónát illeti, a Pilisvörösvári-árok területén a mindvégig itt található - 1920-ig a mezőgazdasági ellátóövezet, majd az átmeneti övezet részét képező - Pilisborosjenő érdemel megkülönböztetett figyelmet. Üröm 1941-től, Pilisvörösvár 1930-tól, Pilisszentiván és Solymár pedig már 1920-tól kiesett a tágabb urbanizációs zónából, ami a Pilisvörösvári-árok területén tapasztalható urbanizációs folyamatok esetlegességét mutatja. Épp ellenkező utat járt be a Piliscsaba, Pilisliget és Pilisjászfalu vizsgálati egység, amely nem függetlenül a Pilisligetre/Klotildligetre érkező betelepülőktől - 1941-re foglalta el helyét a tágabb urbanizációs zóna átmeneti övezetében. A Duna jobb 
partján is találhatunk a tágabb urbanizációs zónába tartozó településeket. Ilyen a Nagy-Budapesttől északra elhelyezkedő, 1910-től 1930-ig az átmeneti övezet, 1941-re pedig már az ipari övezet részének tekinthető Budakalász, valamint két nagy múltú település: az átmeneti övezetbe 1920-tól csatlakozó Szentendre és Visegrád. Előbbi az agrárfoglalkoztatottak arányának csökkenése miatt 1941-ben már a tisztviselőtelepek jellegzetességeit mutatja.

\section{Jegyzetek}

1 A szerzőpáros mindkét tagja történész végzettséggel is rendelkezik. Buskó Tibor László egyetemi kutatásai során a Rákos menti községek társadalmi átalakulásával foglalkozott behatóan, mely témát szakdolgozatában dolgozta fel, Jószai Attila készülő doktori disszertációja pedig a Csepel-sziget északi részének szuburbanizációs folyamatait vizsgálja. A két oktató a 2012-ben általuk meghirdetett urbanisztika TDK résztvevőivel - mintegy 15 egyetemi hallgató - végezte az adatgyüjtést, akiknek ezúton mondanak köszönetet.

2 Ettől csak napjaink „harmadik világának” városfejlődése tér el: itt nem az ipari koncentráció, hanem a vidéki térségek válsága indítja el a városrobbanást.

3 A fogalmat többféle szempontból is lehet értelmezni. A továbbiakban a fejlődéstörténeti szakmai definícióra koncentrálunk, és nem foglalkozunk a hazai jogszabályok definícióival. Ennek oka, hogy ezek a jelen állapot alapján értelmeznek. Ilyen az Országos Területfejlesztési Koncepció meghatározása: „Olyan összeépült településegyüttes, melyben egy központi város és az azt körülvevő térség, elővárosi gyűrű között különösen szoros kapcsolat van, a foglalkoztatottak nagy arányban ingáznak az agglomeráció központi városába. Az agglomerációkat általában magas népsűrűség, gazdasági aktivitás jellemzi.” Példánkban az „összeépült településegyüttes” fogalmával nem értünk egyet: bár a definíció szinte azonos az elmúlt évtizedek fogalommeghatározásával, az „összeépült” kifejezés az aktuális fővárosi és Balaton környéki helyzet miatt került bele a definícióba.

4 A továbbiakban csak az ipari koncentráció révén létrejött, azaz a nagyvárosi agglomerációval foglalkozunk. A szakirodalom megkülönböztet ipari agglomerációt (mint a Ruhr-vidék) és üdülőhelyi agglomerációt (Garda-tó térsége, Balaton).

5 A budapesti agglomeráció településeinek listája megtalálható 2011. évi LXXXVIII. törvényben a Budapesti Agglomeráció Településrendezési Tervéről szóló 2005. évi LXIV. törvény módosításáról.

6 A vonatkozó népszámlálási kötetek mellett felhasználtuk még a Központi Statisztikai Hivatal által 1969-ben publikált népmozgalmi kötet (KSH 1969) adatait is.

7 1910-től 1930-ig „őstermelők”; kiegészítve a mezőgazdasági keresőtevékenységet folytató „napszámosok” becsült számával.

8 A kommunalitásértékeket a hozzájuk tartozó komponensmátrix-értékek négyzetre emelésével kaptuk meg.

9 Arra pedig, hogy egy 1910-ben még az urbanizációból kimaradó település 1941-re a közvetlen urbanizációs zónába küzdje fel magát, mindössze Érd volt képes.

10 A Budapesttől viszonylag távol eső, jelentékeny belső urbanizációs potenciállal rendelkező Vác urbanizálódásában nemcsak Budapest közelsége, de számos autochton folyamat is szerepet játszhatott. 


\section{Irodalom}

Barta Gy., Beluszky P. (szerk.) (1999): Társadalmi-gazdasági átalakulás a budapesti agglomerációban. Regionális Kutatási Alapítvány, Budapest

Berend T. I., Ránki Gy. (1961): A Budapest környéki ipari övezet kialakulásának és fejlődésének kérdéséhez. Akadémiai Kiadó, Budapest (Tanulmányok Budapest múltjából; 14.)

van den Berg, L., Drewett, R., Klaassen, L. H., Rossi, A., Vijverberg, C. H. T. (1982): A study of growth and decline. Pergamon Press, Oxford, New York

Bodor A. (1933): Budapest hatása a környékbeli földárak és müvelési ágak átalakulására. Központi Statisztikai Hivatal, Budapest (Statisztikai Közlemények; 64.)

Boross M. (1956): A nagybudapesti és pestkörnyéki paradicsomkultúra gazdasági és néprajzi vizsgálata. Néprajzi Értesito", 38., 129-161.

Buskó T. L. (2001): A centrum-periféria relációk Budapest és Rákosvidék között (1872-1990) avagy egy integrációs folyamat tanulságai. Tér és Társadalom, 3-4., 125-146.

Csoma Zs. (1998): Falusi környezet - nagyvárosi ellátás. Budapest a kert-, szőlő- és bortörténet városa. Agrártörténeti, agrártudomány-történeti városmonográfia Pest, Buda és Óbuda városegyesitésének 125. évfordulóján. Centrál-Európa Alapítvány, Budapest

Dövényi Z., Kovács Z. (1999): A szuburbanizáció térbeni-társadalmi jellemzői Budapest környékén. Földrajzi Értesíto", 1-2., 33-57.

Ehleiter J. (2007): Urbanisztika és regionalitás. HVG-Orac, Budapest

Enyedi Gy. (1988): A városnövekedés szakaszai. Akadémiai Kiadó, Budapest

Gaebe, W. (2004): Urbane Räume. Eugen Ulmer, Stuttgart

Izsák É. (2003): A városfejlődés természeti társadalmi tényezői - Budapest és környéke. Napvilág Kiadó, Budapest

KSH [Központi Statisztikai Hivatal] (1969): A népmozgalom föbb adatai községenként 1901-1968. KSH, Budapest

Lord A. (1901): Budapest telekpolitikája. Városrendezési tanulmány. Hornyánszky Viktor könyvnyomdája, Budapest

Saunders, P. (1985): Space, the city and urban sociology. In: Gregory, D., Urry, J. (eds.): Social relations and spatial structures. Macmillan, London, 67-89.

Savage M., Warde A. (1993): Urban sociology, capitalism and modernity. Macmillan, London

Timár J. (2006): Az agglomerálódástól a szuburbanizációig: „Tértermelés” a posztszocialista Magyarországon In: Csapó T., Kocsis Zs. (szerk.): Agglomerációk és szuburbanizálódás Magyarországon. Savaria University Press, Szombathely, 35-51.

Tóth J. (2006): Az agglomerálódás stádiumai. In: Csapó T., Kocsis Zs. (szerk.): Agglomerációk és szuburbanizálódás Magyarországon. Savaria University Press, Szombathely, 6-15.

Tózsa I. (2011): Közigazgatási urbanisztika I. - Településtan. Aula Kiadó, Budapest

Vörös K. (1978): A világváros útján 1896-1918. In: Spira Gy., Vörös K. (1978): Budapest története a márciusi forradalomtól az öszirózsás forradalomig. Akadémiai Kiadó, Budapest, 525-772. (Budapest története; 4 .) 